Ghasemi, Share, et al. Published in Ecological Research. 33(3) 2018: 737-747.

Rasoul Ghasemi $\cdot$ Hoorieh Share $\cdot$ Roza Sharifi

Robert S. Boyd • Nishanta Rajakaruna

\title{
Inducing $\mathrm{Ni}$ sensitivity in the $\mathrm{Ni}$ hyperaccumulator plant Alyssum inflatum Nyárády (Brassicaceae) by transforming with CAX1, a vacuolar mem- brane calcium transporter
}

\begin{abstract}
The importance of calcium in nickel tolerance was studied in the nickel hyperaccumulator plant Alyssum inflatum by gene transformation of $C A X 1$, a vacuolar membrane transporter that reduces cytosolic calcium. CAX1 from Arabidopsis thaliana with a CaMV35S promoter accompanying a kanamycin resistance gene was transferred into $A$. inflatum using Agrobacterium tumefaciens. Transformed calli were subcultured three times on kanamycin-rich media and transformation was confirmed by PCR using a specific primer for $C A X 1$. At least 10 callus lines were used as a pool of transformed material. Both transformed and untransformed calli were treated with varying concentrations of either calcium $(1-15 \mathrm{mM})$ or nickel $(0$ $500 \mu \mathrm{M})$ to compare their responses to those ions. Increased external calcium generally led to increased callus biomass, however, the increase was greater for untransformed callus. Further, increased external calcium led to increased callus calcium concentrations. Transformed callus was less nickel tolerant than untransformed callus: under increasing nickel concentrations callus relative growth rate was significantly less for transformed callus. Transformed callus also con-
\end{abstract}

R. Ghasemi $(\bowtie)$

Department of Biology, Faculty of Sciences, Payam Noor

University, Tehran, Iran

H. Share $\cdot$ R. Sharifi

Department of Biology, Faculty of Sciences, Payam Noor

University, Center of Isfahan, Isfahan, Iran

R. S. Boyd

Department of Biological Sciences, Auburn University, Auburn, AL, USA

N. Rajakaruna

Biological Sciences Department, California Polytechnic State University, San Luis Obispo, CA, USA

N. Rajakaruna

Unit for Environmental Sciences and Management, North-West University, Private Bag X6001, Potchefstroom 2520, South Africa tained significantly less nickel than untransformed callus when exposed to the highest external nickel concentration $(200 \mu \mathrm{M})$. We suggest that transformation with $C A X 1$ decreased cytosolic calcium and resulted in decreased nickel tolerance. This in turn suggests that, at low cytosolic calcium concentrations, other nickel tolerance mechanisms (e.g., complexation and vacuolar sequestration) are insufficient for nickel tolerance. We propose that high cytosolic calcium is an important mechanism that results in nickel tolerance by nickel hyperaccumulator plants.

Keywords $\mathrm{Ca}: \mathrm{Mg}$ ratio $\cdot \mathrm{CAX1} \cdot \mathrm{Genetic}$ transformation $\cdot \mathrm{Ni}$ tolerance $\cdot$ Serpentine

\section{Introduction}

Plants found on serpentine soils have contributed greatly to the development of ecological and evolutionary theory (Harrison and Rajakaruna 2011) and have provided model systems for the study of ecophysiology (Palm and Van Volkenburgh 2014), ecological genetics (von Wettberg and Wright 2011; Selby et al. 2014), and speciation (Kay et al. 2011). Serpentine soils are challenging habitats for most plants because they are often deficient in plant essential macronutrients, have a calcium-to-magnesium $(\mathrm{Ca}: \mathrm{Mg}$ ) quotient of less than 1 (often < 1:10; Rajakaruna et al. 2009), and have elevated levels of toxic heavy metals such as nickel $(\mathrm{Ni})$, cadmium $(\mathrm{Cd})$, cobalt (Co), and chromium (Cr) (Brady et al. 2005; Kazakou et al. 2008; O'Dell and Rajakaruna 2011). The physical characteristics of serpentine soils (which are often rocky and shallow), and particularly their generally low soil moisture retention capacity, also impose water stress on plants (Palm and Van Volkenburgh 2014). Due to these intense selective pressures, serpentine soils promote speciation and the evolution of edaphic endemism, contributing to unique floras with high rates of rarity, 
Table 1 Changes made to the MS (Murashige and Skoog) medium composition to avoid depletion of ammonium and potassium in the Ca treatments

\begin{tabular}{lll}
\hline Chemicals & Concentrations in MS medium $(\mathrm{mM})$ & Concentrations in modified MS medium (mM) \\
\hline $\mathrm{NH}_{4} \mathrm{NO}_{3}$ & 20.6 & 25.6 \\
$\mathrm{KNO}_{3}$ & 18.8 & 23.8 \\
$\mathrm{CaCl}_{2}$ & 3 & 3 \\
$\mathrm{KH}_{2} \mathrm{PO}_{4}$ & 1.2 & 0 \\
$\mathrm{KCl}$ & 0 & 2 \\
$\mathrm{KH}_{2} \mathrm{PO}_{4}$ & 0 & 1.2 \\
\hline
\end{tabular}

Table 2 Nitrate changes in MS (Murashige and Skoog) medium for the treatments of Ca (mM)

\begin{tabular}{|c|c|c|c|c|c|}
\hline \multirow[t]{2}{*}{ Values for each treatment } & \multicolumn{5}{|c|}{ Final $\mathrm{Ca}$ concentration in medium (treatments) } \\
\hline & 1 & 3 & 5 & 10 & 15 \\
\hline $\mathrm{CaCl}_{2}$ concentration & 1 & 3 & 3 & 3 & 3 \\
\hline Added $\mathrm{Ca}\left(\mathrm{NO}_{3}\right)_{2}$ & 0 & 0 & 2 & 7 & 12 \\
\hline Increase in nitrate concentration due to added $\mathrm{Ca}\left(\mathrm{NO}_{3}\right)_{2}$ & 0 & 0 & 4 & 14 & 24 \\
\hline Decrease in ammonium nitrate + potassium nitrate & 0 & 0 & $2+2$ & $7+7$ & $12+12$ \\
\hline Final ammonium nitrate & 25.6 & 25.6 & 23.6 & 18.6 & 13.6 \\
\hline Final potassium nitrate & 23.8 & 23.8 & 21.8 & 16.8 & 11.8 \\
\hline
\end{tabular}

endemism, and disjunct distributions (Anacker 2011, 2014).

It is unclear whether a particular chemical or physical factor is largely responsible for serpentine tolerance (Brady et al. 2005); it is generally believed that serpentine tolerance in plants results from adaptations to a combination of chemical, physical, and biotic stressors (i.e. serpentine syndrome sensu Jenny 1980). However, the low soil $\mathrm{Ca}: \mathrm{Mg}$ quotient (often $<1: 10$, see Bradshaw 2005; Palm et al. 2012) and high heavy metal concentrations, particularly Ni (Gabbrielli et al. 1989; Burrell et al. 2012; Doubkova and Sudova 2014), have received much attention as key factors driving evolution of plant serpentine tolerance.

Plants growing on serpentine soils have a range of strategies to deal with the disproportionately low soil $\mathrm{Ca}: \mathrm{Mg}$ ratio (Palm et al. 2012; Palm and Van Volkenburgh 2014). For example, some plants have a requirement for and tolerance of high Mg (Main 1981; Johnston and Proctor 1984; Asemaneh et al. 2007) while others have an enhanced ability for $\mathrm{Ca}$ uptake (Rajakaruna et al. 2003; O'Dell et al. 2006; Ghasemi and Ghaderian 2009; Veatch Blohm et al. 2013) or the ability to exclude Mg (O'Dell and Claassen 2006; Sambatti and Rice 2007), enabling them to survive the relatively high $\mathrm{Mg}$ concentrations typical of serpentine soils. The discovery of genes responsible for maintenance of plant $\mathrm{Ca}: \mathrm{Mg}$ homeostasis (Li et al. 2001; Cheng et al. 2003; Turner et al. 2008, 2010; Tang et al. 2015) is now making it possible to explore the genetic basis for tolerance of low soil $\mathrm{Ca}: \mathrm{Mg}$, a key factor associated with serpentine tolerance. Recent work by Tang et al. (2015) documents a novel function of the CBL-CIPK signaling network in vacuolar sequestration of excessive $\mathrm{Mg}^{2+}$, thereby helping plants to survive the high $\mathrm{Mg}^{2+}$ concentrations typical of serpentine soils. Cheng et al. (2003) showed that $C A X 1$ (a calcium-proton antiporter on the tonoplast) maintains $\mathrm{Ca}$ homeostasis in plant cells by pumping excess $\mathrm{Ca}$ from the cytoplasm into the vacuole. However, under the low soil $\mathrm{Ca}$ concentrations typical of serpentine soils, cytoplasmic $\mathrm{Ca}$ can become too low in the presence of $C A X 1$ activity. Bradshaw (2005) showed that CAX1 mutants of Arabidopsis thaliana (lacking the allele) exhibit greater tolerance of serpentine soils due to their higher cytoplasmic $\mathrm{Ca}$ concentations. Whether $C A X 1$ mutations play a role in the adaptation of natural plant populations to serpentine soil, however, is largely unexplored.

Tolerance to heavy metals, especially $\mathrm{Ni}$, has also been the focus of studies examining tolerance and adaptation to serpentine soils (Freeman et al. 2004; Ingle et al. 2005; Meindl et al. 2014; Ghasemi et al. 2015a, b). Although Ni is an essential micronutrient (Polacco et al. 2013), high levels of $\mathrm{Ni}$, as found in serpentine soils, can be toxic to plants (Yusuf et al. 2011). Plants have varying strategies to deal with $\mathrm{Ni}$, including exclusion or restriction of entry of $\mathrm{Ni}$ into the cytoplasm and chelation of $\mathrm{Ni}$ by phytochelatins, metallothioneins, nicotianamide, organic acids, and amino acids, followed by sequestration in the vacuole (Ahmad and Ashraf 2011; Yusuf et al. 2011; Amari et al. 2016). Some plants can hyperaccumulate $\mathrm{Ni}$ (defined as $>1000 \mu \mathrm{g} / \mathrm{g}$ dry weight leaf tissue; van der Ent et al. 2013) and the genetic basis (Pollard et al. 2002; Verbruggen et al. 2009) for and ecological and evolutionary significance (Cecchi et al. 2010; Boyd 2014; Cappa and Pilon-Smits 2014) of Ni hyperaccumulation has received much attention.

The importance of $\mathrm{Ca}$ in alleviating metal toxicity is also known (Aziz et al. 2015). Calcium is an essential nutrient for plant growth, development, and metabo- 
(a)

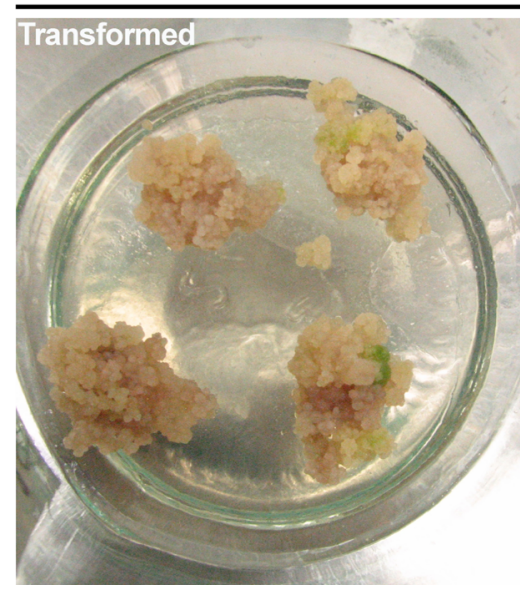

Fig. 1 a Transformed (left) and untransformed (right) calli of Alyssum inflatum on media containing $100 \mathrm{mg} / \mathrm{L}$ kanamycin. The untransformed callus has not grown after transfer onto the medium. b PCR detection of the multiplied fragment by using a specific primer for CAX1. Lanes (from L-R) are: 1) molecular

lism, regulating the function of proteins and membrane transport systems as well as gene expression (Bush 1995; White and Broadley 2003; Hepler 2005). Calcium is also involved in the synthesis of glutathione, a precursor of phytochelatin, thereby contributing to the inactivation and detoxification of metal ions entering the cytoplasm (Lopez Climent et al. 2014). An increase in Ca can therefore mitigate the deleterious effects of metals (Rengel 1992; Siddiqui et al. 2012; Eller and Brix 2016). The role of $\mathrm{Ca}$ in $\mathrm{Ni}$ tolerance has been studied in agricultural plants (Matraszek and Hawrylak Nowak 2010; Siddiqui et al. 2011; Mozafari et al. 2014) and in plants adapted to serpentine soils (Gabbrielli et al. 1989; Chaney et al. 2008). High cytosolic Ca contributes to alleviating $\mathrm{Ni}$ (and other metal) toxicity by increasing antioxidant enzyme activities and osmolytes such as proline (Siddiqui et al. 2011), reducing lipid peroxidation of cell membranes (Gong et al. 1997a, b; Jiang and Huang 2001; Hirschi 2004), and by heavy metal detoxification (Antosiewicz and Hennig 2004; Jauregui Zùñiga et al. 2005). Magnesium, an important constituent for chlorophyll biosynthesis, also plays an essential role in decreasing heavy metal toxicity, both by reducing heavy metal uptake (Abul Kashem and Kawai 2007) and by enhancing antioxidant production (Chou et al. 2011).

Interactions between all three ions $(\mathrm{Ca}, \mathrm{Mg}$, and $\mathrm{Ni})$ are complex. Magnesium may interfere with the uptake of $\mathrm{Ca}, \mathrm{Ca}$ may reduce $\mathrm{Mg}$ toxicity, and both $\mathrm{Mg}$ and $\mathrm{Ca}$ may reduce Ni toxicity (Johnston and Proctor 1981; Gabbrielli and Pandolfini 1984; Heikal et al. 1989; Vergnano Gambi et al. 1992; Izosimova 2005; Chaney et al. 2008; Ghasemi and Ghaderian 2009). Plants adapted to serpentine soils provide ideal model systems to explore the interplay among these ions, particularly how serpentine plants are able to alleviate $\mathrm{Ni}$ toxicity under the low soil $\mathrm{Ca}: \mathrm{Mg}$ ratios typical of serpentine soils. Molecular approaches can provide powerful tools (b)

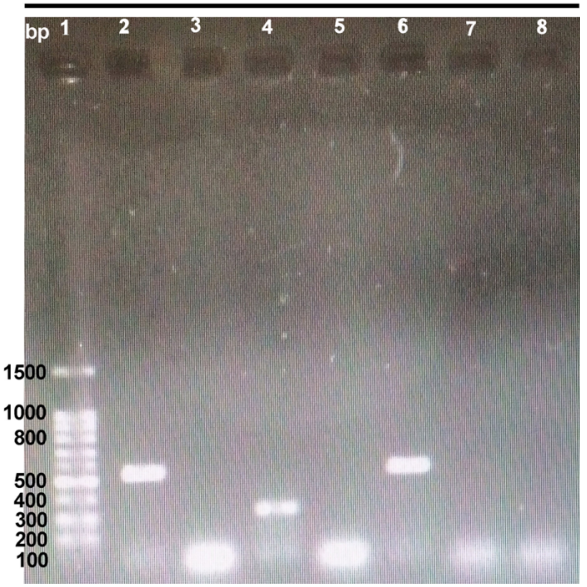

weight marker of DNA, 2) callus of Arabidopsis thaliana, 3) untransformed callus of Alyssum inflatum, 4) transformed callus of A. inflatum, 5) A. inflatum plant, 6) A. thaliana plant, 7) A. saxatile plant, 8) negative control

to illustrate the underlying genetic mechanisms of serpentine tolerance (e.g., Turner et al. 2010; Burrell et al. 2012; Arnold et al. 2016; Porter et al. 2016).

Here, we examine the role of $\mathrm{Ca}$ in Ni tolerance using a Ni hyperaccumulator plant (Alyssum inflatum) that grows on serpentine soils in Iran. We transformed cells of A. inflatum, using Agrobacterium tumefaciens to insert the vacuolar membrane $\mathrm{Ca}^{2+} / \mathrm{H}^{+}$antiporter $C A X 1$ from Arabidopsis thaliana. We then treated cells with varying levels of $\mathrm{Ca}$ or $\mathrm{Ni}$, measuring growth (as dry weight) and $\mathrm{Ca}$ and $\mathrm{Ni}$ concentrations in calli in response to those treatments. We sought to answer the following questions: (1) how do untransformed and transformed calli respond (in growth and callus $\mathrm{Ca}$ concentrations) to varying external Ca concentrations?, and (2) how do untransformed and transformed calli respond (in growth and callus $\mathrm{Ni}$ concentrations) to varying external Ni concentrations?

\section{Materials and methods}

Alyssum inflatum Nyarady (Brassicaceae) is a serpentine endemic perennial plant from western Iran belonging to section Odontarrhena (Ghasemi et al. 2009a, b; Ghasemi and Ghaderian 2009; Ghasemi et al. 2015a, b). Seeds of $A$. inflatum were harvested from serpentine soils in

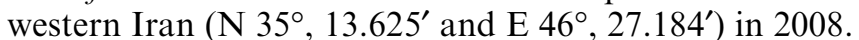
Approximately 50,000 seeds were collected as a bulk sample from $\sim 70$ plants and mixed thoroughly. Seeds were stored at $4{ }^{\circ} \mathrm{C}$ for three months to break dormancy.

Seeds were surface-sterilized with $70 \%$ ethanol ( $2 \mathrm{~min}), 2.5 \%$ sodium hypochlorite $(15 \mathrm{~min})$ and rinsed six times (each time for $2-5 \mathrm{~min}$ ) using distilled sterile water. Seeds were germinated and plants grown on modified Hoagland solution containing: $1 \mathrm{mM}$ $\mathrm{Ca}\left(\mathrm{NO}_{3}\right)_{2}, 0.5 \mathrm{mM} \mathrm{KNO}_{3}, 0.5 \mathrm{mM} \mathrm{MgSO}_{4}, 0.1 \mathrm{mM}$ 
$\mathrm{KH}_{2} \mathrm{PO}_{4}, \quad 10 \mu \mathrm{M} \quad \mathrm{H}_{3} \mathrm{BO}_{3}, \quad 0.1 \mu \mathrm{M} \quad \mathrm{ZnSO}_{4}, \quad 0.1 \mu \mathrm{M}$ $\mathrm{CuSO}_{4}, 0.1 \mu \mathrm{M} \mathrm{Na} \mathrm{MoO}_{4}, 2 \mu \mathrm{M} \mathrm{MnSO}_{4}, 1 \mu \mathrm{M} \mathrm{NaCl}$, and $5 \mu \mathrm{M}$ FeEDTA. Growth media were solidified using $0.85 \%$ agar-agar. Seeds and resulting seedlings were kept in a growth chamber with a 8:16 dark:light regime and temperature range of $24-26^{\circ} \mathrm{C}$.

Plasmid and bacteria

We used pBIN19, a binary disarmed vector carrying two kanamycin resistance genes for selecting transformed cells and agrobacterium, as well as the $C A X 1$ gene which was located in T-DNA. This plasmid was cloned in TOP10 E. coli. The plasmid was extracted from E. coli (mini-prep method; Tarczynski et al. 1994) and transferred into Agrobacterium tumefaciens strain GV3101 possessing a chromosomal rifampicin resistance gene and a gentamicin resistance gene on its helper plasmid. Transformation was performed according to An et al. (1988).

\section{Plant cell transformation}

Transformed Agrobacterium were cultured in liquid LB medium including $10 \mathrm{mg} / \mathrm{L}$ rifampicin, $10 \mathrm{mg} / \mathrm{L}$ kanamycin, and $100 \mathrm{mg} / \mathrm{L}$ acetocyringone (Ditt et al. 2001) for $18 \mathrm{~h}$ to reach OD600 of $0.8-1$. The medium was centrifuged at $10000 \mathrm{rpm}$ for $10 \mathrm{~min}$, the supernatant discarded, and the pellet re-suspended in MS medium (Murashige and Skoog 1962; $\mathrm{pH}=5.7$, to $\mathrm{OD}_{600}=1$ ). Shoots of 35-day-old seedlings, which were used as explants, were wounded at their tips and internodes and then suspended/submerged in a solution containing the bacterium for $30 \mathrm{~min}$. Explants were semi-dried using filter paper, and then put on MS medium with no added hormone or antibiotic for three days (8:16 h dark:light regime and constant $25^{\circ} \mathrm{C}$ ).

After three days, explants were submerged in liquid MS medium containing $150 \mathrm{mg} / \mathrm{L}$ cefotaxime for four min and then rinsed with liquid MS medium. Explants were semi-dried and sub-cultured on solidified MS medium including $300 \mathrm{mg} / \mathrm{L}$ carbenicillin and $100 \mathrm{mg} / \mathrm{L}$ kanamycin as selective antibiotics for three days at $24{ }^{\circ} \mathrm{C}$ and a $16: 8 \mathrm{~h}$ light:dark regime.

\section{Confirmation of transformation}

Transformation was confirmed in two ways: (1) by growing calli on a selective medium, and (2) with PCR by using a $C A X 1$ specific primer. Calli were continually subcultured on a medium containing $100 \mathrm{mg} / \mathrm{L}$ kanamycin. As a control, some untransformed calli were also subcultured on kanamycin-supplemented media.

For PCR, the primers were designed using Primer Blast tool at NCBI. The selected primer was $5^{\prime}$ CCAAGCATAACGGCGAAAGG $3^{\prime}$ as the forward oligonucleotide and 5' GACCACCCAATGTAGGACCG $3^{\prime}$ as the reverse one, based on the cDNA sequence (which was predicted to give a $343 \mathrm{bp}$ product) of CAX1 in Arabidopsis thaliana. PCR conditions were: first denaturing $\left(94^{\circ} \mathrm{C}, 4 \mathrm{~min}, 1\right.$ cycle), multiplication step including 30 cycles (each cycle including denaturing $\left.\left(94{ }^{\circ} \mathrm{C}, 1 \mathrm{~min}\right)\right)$, annealing $\left(52^{\circ} \mathrm{C}, 45 \mathrm{~s}\right)$, and extension $\left(72{ }^{\circ} \mathrm{C}, 75 \mathrm{~s}\right)$, and final extension $\left(72^{\circ} \mathrm{C}, 5 \mathrm{~min}\right)$.

\section{DNA extraction}

Genomic DNA from Arabidopsis thaliana, Alyssum inflatum, $A$. saxatile, calli of $A$. inflatum, and transformed $A$. inflatum and $A$. thaliana was extracted according to Porebski et al. (1997). The congener Alyssum saxatile, and the model Brassicaceae species $A$. thaliana, obtained from Steinkraut Company, Germany and the laboratory of Ute Krämer, University of Bochum, Germany, respectively, were included as reference samples to confirm transformation of A. inflatum calli.

Effect of $\mathrm{Ca}$ on untransformed and transformed $A$. inflatum callus

Untransformed and transformed $A$. inflatum calli were grown on MS medium. The composition of the unmanipulated medium was: $\mathrm{NH}_{4} \mathrm{NO}_{3}, 20.6 \mathrm{mM} ; \mathrm{H}_{3} \mathrm{BO}_{3}$, $0.1 \mathrm{mM} ; \mathrm{CaCl}_{2}, 2.99 \mathrm{mM} ; \mathrm{CoCl}_{2}, 0.1 \mu \mathrm{M} ; \mathrm{MgSO}_{4}$, $1.5 \mathrm{mM}$; $\mathrm{CuSO}_{4}, 0.1 \mu \mathrm{M}$; $\mathrm{KH}_{2} \mathrm{PO}_{4}, 1.25 \mathrm{mM}$; FeEDTA, $0.1 \mathrm{mM} ; \mathrm{KNO}_{3}, 18.79 \mathrm{mM} ; \mathrm{MnSO}_{4}, 10 \mu \mathrm{M}$; KI $5 \mu \mathrm{M} ; \mathrm{Na}_{2} \mathrm{MoO}_{4}, 1.2 \mu \mathrm{M} ; \mathrm{ZnSO}_{4}, 30 \mu \mathrm{M}$. The $\mathrm{Ca}: \mathrm{Mg}$ ratio of this medium is about 2. Alyssum inflatum calli were treated using solutions to vary concentrations of $\mathrm{Ca}$, as $\mathrm{Ca}\left(\mathrm{NO}_{3}\right)_{2}$, in the MS medium to include experimental concentrations of $1,3,5,10$, and $15 \mathrm{mM}$. This range of $\mathrm{Ca}$ concentrations was selected based on previous research (Ghasemi et al. 2015a, b; Ghasemi and Ghaderian 2009). At higher concentrations (5, 10, and $15 \mathrm{mM})$ of $\mathrm{Ca}\left(\mathrm{NO}_{3}\right)_{2}$, the concentrations of nitrate were too high to allow normal plant growth. Therefore, modifications (shown in Tables 1 and 2) were made in the composition of the MS medium. First, concentrations of $\mathrm{NH}_{4} \mathrm{NO}_{3}$ and $\mathrm{KNO}_{3}$ were both increased by $5 \mathrm{mM}$, to 25.6 and $23.8 \mathrm{mM}$, respectively (Table 1). This increase was done to prevent depletion of ammonium and potassium in media at higher $\mathrm{Ca}$ treatments. $\mathrm{KH}_{2} \mathrm{PO}_{4}$ was removed and $\mathrm{K}_{2} \mathrm{HPO}_{4}$ was added $(1.2 \mathrm{mM})$ to compensate for the $\mathrm{K}$ depletion resulting from removing $\mathrm{KNO}_{3}$ in some treatments. In addition, $\mathrm{KCl}$ was used to compensate for the $\mathrm{Cl}$ decrease in the $1 \mathrm{mM}$ treatment (in which $\mathrm{CaCl}_{2}$ was used at a low concentration). Second, for Ca treatments, as shown in Table 2, final concentrations of $\mathrm{Ca}$ were achieved by removing $\mathrm{CaCl}_{2}$ or adding $\mathrm{Ca}\left(\mathrm{NO}_{3}\right)_{2}$. In the cases involving addition of $\mathrm{Ca}\left(\mathrm{NO}_{3}\right)_{2}$, equivalent nitrate was decreased by removing $\mathrm{NH}_{4} \mathrm{NO}_{3}$ and $\mathrm{KNO}_{3}$ (Table 2). 
(a)

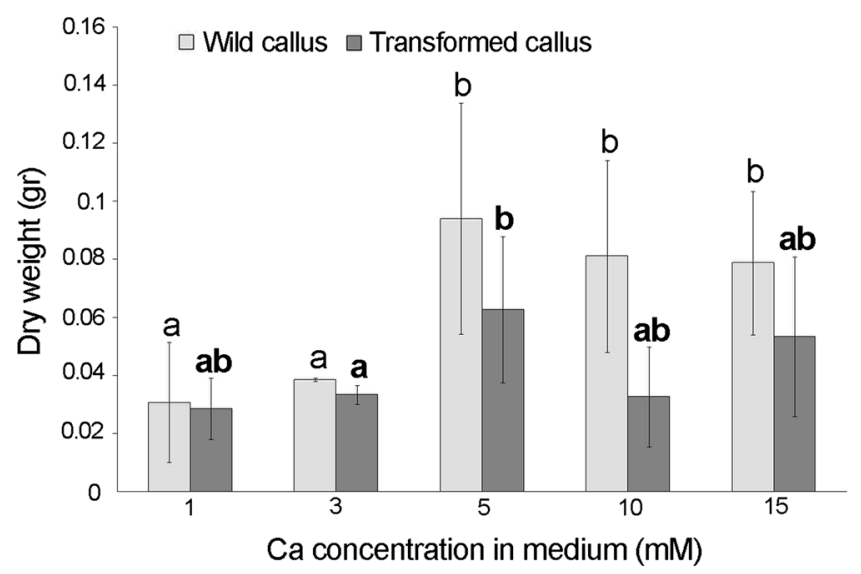

Fig. 2 Effect of Ca concentration in medium on growth of Alyssum inflatum untransformed (wild) and transformed callus. Values are means of 3 replicates \pm SD. Different letters indicate statistically significant differences of $\mathrm{Ca}$ concentration within each type of callus (normal font for wild callus and bold font for transformed callus comparisons) according to Tukey's HSD $(P \leq 0.05)$. a

This experiment was designed to document the response of untransformed and transformed A. inflatum calli to $\mathrm{Ca}$ concentration in the medium, using growth and $\mathrm{Ca}$ concentration of calli as response variables. To measure growth of calli, $0.25-0.35 \mathrm{~g}$ of callus was subcultured in containers and kept at $24{ }^{\circ} \mathrm{C}$ in a $8: 16 \mathrm{~h}$ dark:light period. After 45 days, calli were dried at $70{ }^{\circ} \mathrm{C}$ for $24 \mathrm{~h}$ and dry mass values were recorded. Calli were desorbed using desorption solutions before digesting so that $\mathrm{Ca}$ measurements would reflect internal cellular concentrations rather than $\mathrm{Ca}$ adsorbed to cell wall components. Calli were desorbed first in an icecooled solution containing $1 \mathrm{~mm}$ MES (pH 5.7), and $5 \mathrm{~mm} \mathrm{MgSO}_{4}$ for $10 \mathrm{~min}$ and then with a solution containing $1 \mathrm{~mm}$ MES (pH 5.7), $5 \mathrm{~mm} \mathrm{MgSO}$, and $5 \mathrm{~mm} \mathrm{Na} \mathrm{N}_{2}$ EDTA, for $5 \mathrm{~min}$. Callus $\mathrm{Ca}$ concentrations were measured by digesting dried calli using $67 \%$ nitric acid at room temperature for $24 \mathrm{~h}$ and then heating solutions to $90{ }^{\circ} \mathrm{C}$ for $1 \mathrm{~h}$. Suspensions were cooled to room temperature, $30 \% \mathrm{H}_{2} \mathrm{O}_{2}$ was added, and then solutions were heated to $90{ }^{\circ} \mathrm{C}$ until clear. Finally, calli were rinsed in ultrapure water twice, each time for 1 min. All desorption steps were performed on ice. Calcium concentrations were measured by atomic absorption spectrophotometry (AAS, Philips, model: PU9100X, The Netherlands).

Effect of Ni on untransformed and transformed $A$. inflatum callus

The response of untransformed $A$. inflatum callus to Ni was determined by growing callus in media containing a range of $\mathrm{Ni}$ concentrations. Appropriate volumes of a $\mathrm{NiSO}_{4}$ stock were added to generate medium $\mathrm{Ni}$ concentrations ranging from 0 to $500 \mu \mathrm{M}(0,25,50,100$, (b)

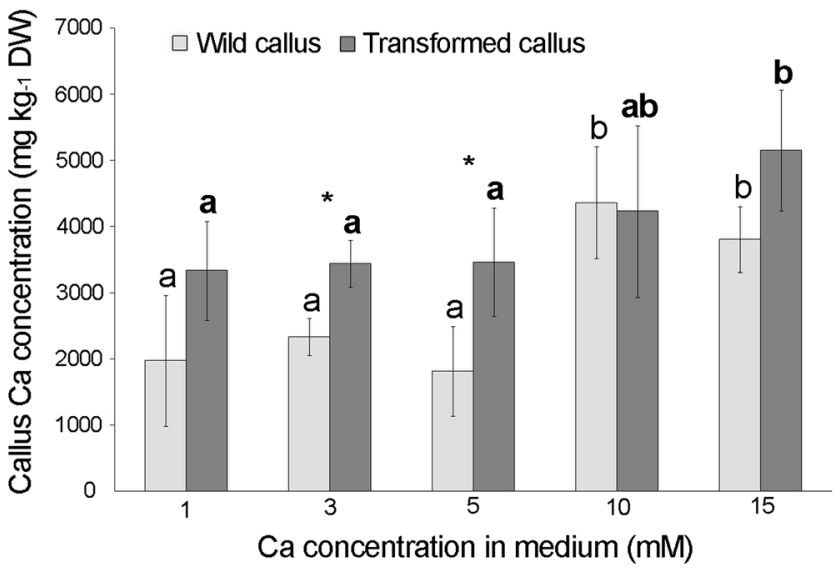

Results for callus dry weight data. No statistically significant difference was observed between untransformed and transformed calli at each Ca concentration ( $t$ test, $P \leq 0.05$ ). b Concentration of $\mathrm{Ca}\left(\mathrm{mg} \mathrm{Ca} \mathrm{kg}{ }^{-1} \mathrm{DW}\right)$ in callus. *Indicates significant difference between untransformed and transformed calli at each Ca concentration in the medium ( $t$ test, $P \leq 0.05$ )

$200,300,350,400,500 \mu \mathrm{M})$. Tolerance of Ni was documented by measuring callus dry weight and tissue $\mathrm{Ni}$ concentrations. Callus growth (as dry weight) and $\mathrm{Ni}$ concentrations were measured using the same methods as outlined above for $\mathrm{Ca}$.

\section{Statistical analyses}

Analysis of Variance (ANOVA) was used to determine the effects of the various treatments and their interactions. For the experiments testing the response of untransformed and transformed calli to varying $\mathrm{Ca}$ and $\mathrm{Ni}$ concentrations, in which callus growth and callus $\mathrm{Ca}$ and $\mathrm{Ni}$ concentrations were measured, 2-way ANOVAs were used. Callus type and $\mathrm{Ca}$ concentration were the main effects and the interaction was included in the model. Multiple comparisons were performed by Tukey's HSD. Simple comparisons between two groups were performed by t-tests. All statistical analyses used the Statistical Package for the Social Sciences (SPSS) software (version 16).

\section{Results}

Transformation of $A$. inflatum

Transformed calli were able to grow on media containing $100 \mathrm{mg} / \mathrm{L}$ kanamycin (Fig. 1a-left) whereas untransformed calli did not grow in the presence of kanamycin (Fig. 1a-right). As shown in Fig. 1b, PCR revealed that the fragment was present in plants of Arabidopsis thaliana, in callus of $A$. thaliana, and in transformed callus of Alyssum inflatum. PCR did not 
Table 3 Two-way ANOVA analyses of the effects of callus type (untransformed and transformed) and $\mathrm{Ca}$ concentrations in medium on callus growth and $\mathrm{Ca}$ concentration in calli of Alyssum inflatum

\begin{tabular}{|c|c|c|c|c|}
\hline \multirow[b]{2}{*}{ Source of changes } & \multicolumn{2}{|c|}{ Callus growth } & \multicolumn{2}{|c|}{$\begin{array}{l}\text { Callus } \mathrm{Ca} \text { con- } \\
\text { centration }\end{array}$} \\
\hline & $d f F$ value & $P$ value & $F$ value & $P$ value \\
\hline Callus type & 16.11 & 0.015 & 4.67 & 0.008 \\
\hline $\mathrm{Ca}$ concentration & 44.03 & 0.023 & 7.89 & 0.011 \\
\hline Callus type*Ca concentration & $4 \quad 0.89$ & 0.486 & 0.67 & 0.623 \\
\hline
\end{tabular}

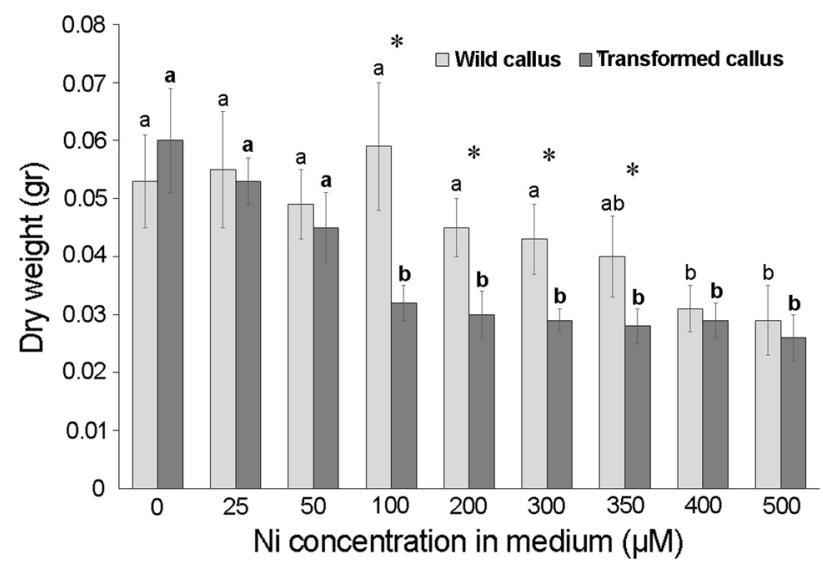

Fig. 3 Mean growth (dry weight) of untransformed (wild) and transformed Alyssum inflatum callus in response to varying $\mathrm{Ni}$ concentrations in the medium. Values are means of 3 replicates $\pm \mathrm{SD}$. Letters indicate statistically different means (normal font for wild callus and bold font for transformed callus comparisons) according to Tukey's HSD $(P \leq 0.05)$. *Indicates significant difference between untransformed and transformed calli at each Ni concentration in the medium ( $t$ test, $P \leq 0.05$ )

show the fragment in plants of $A$. inflatum, untransformed callus of $A$. inflatum, and plants of the congener, A. saxatile (Fig. 1b).

Effect of $\mathrm{Ca}$ on untransformed and transformed $A$. inflatum callus

Two-way ANOVA revealed significant effects of both callus type (untransformed vs. transformed) and $\mathrm{Ca}$ concentration in the medium on callus growth (Table 3 ). There was, however, no significant interaction between callus type and medium $\mathrm{Ca}$ concentration. As shown in Fig. 2a, growth by untransformed callus was generally greater than that of transformed callus, although growth did not differ statistically when compared at any particular medium $\mathrm{Ca}$ concentration. Calcium concentration in the medium also significantly affected callus dry weight, with a general trend of increasing dry weight with increases in medium $\mathrm{Ca}$ concentration (Fig. 2a). This trend was most pronounced for untransformed

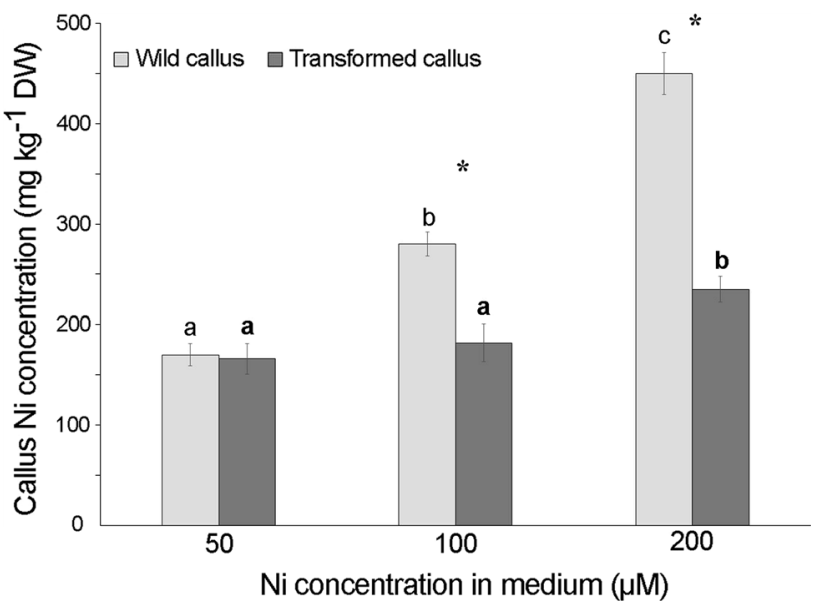

Fig. 4 Nickel concentrations in untransformed (wild) and transformed calli of Alyssum inflatum grown in media containing different Ni levels. Values are means of 3 replicates \pm SD. Letters indicate statistically different $\mathrm{Ni}$ concentrations between the same type of callus (normal font for wild callus and bold font for transformed callus comparisons) treated with different Ni concentrations according to Tukey's HSD $(P \leq 0.05)$. *Indicates statistically significant difference between $\mathrm{Ni}$ concentrations of untransformed and transformed calli at the same Ni concentration, according to a $t$ test $(P \leq 0.05)$

callus, despite the lack of significance for the interaction term in the ANOVA (Table 3).

Two-way ANOVA also revealed significant effects of both callus type (untransformed vs. transformed) and Ca concentration in the medium on Ca concentration in calli (Table 3). In general, transformed callus contained higher levels of $\mathrm{Ca}$, although statistical comparisons between the two callus types at each $\mathrm{Ca}$ concentration in the medium revealed statistically higher $\mathrm{Ca}$ in transformed calli only for the 3 and $5 \mathrm{mM} \mathrm{Ca}$ treatments (Fig. 2b). Not surprisingly, Ca concentration in the calli generally increased with $\mathrm{Ca}$ concentration in the medium (Fig. 2b). There was no significant interaction between callus type and $\mathrm{Ca}$ concentration in the medium (Table 3), indicating Ca concentrations in the two types of calli responded similarly to $\mathrm{Ca}$ in the medium.

Effect of $\mathrm{Ni}$ on untransformed and transformed $A$. inflatum callus

Untransformed callus was relatively $\mathrm{Ni}$ tolerant. As shown in Fig. 3, untransformed callus growth did not decline until $\mathrm{Ni}$ concentration reached $400 \mu \mathrm{M} \mathrm{Ni}$ in the medium. In contrast, transformed callus was comparatively sensitive to $\mathrm{Ni}$ and a significant decrease in growth was observed at $100 \mu \mathrm{M}$. Calli also differed in their Ni concentrations, depending on the Ni level in the medium. At low Ni concentration (sub-lethal level, $50 \mu \mathrm{M}$ $\mathrm{Ni}$ in medium), there was no difference between $\mathrm{Ni}$ concentrations of untransformed and transformed calli (Fig. 4). At higher Ni concentrations in the medium (100 


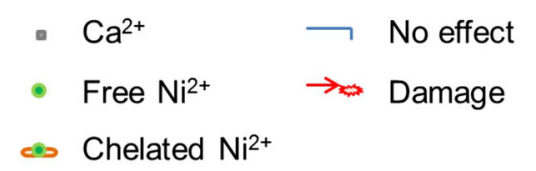

$\left[\mathrm{Ca}^{2+}\right]$ cyt $\uparrow:$ No damage by $\mathrm{Ni}$

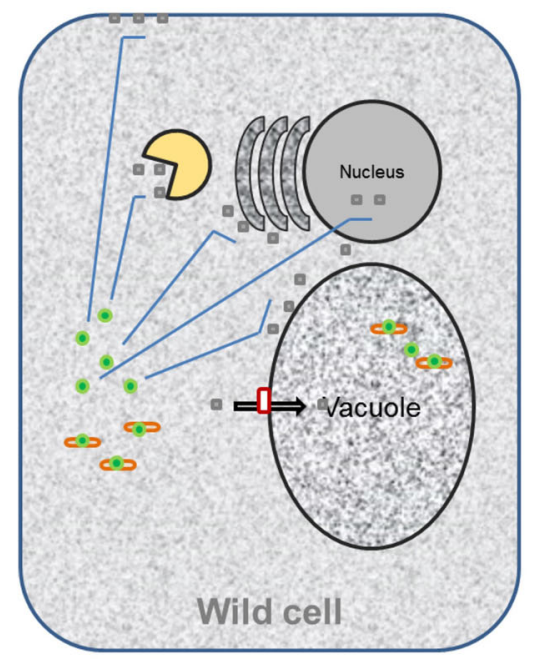

Fig. 5 Proposed model for the role of high cytosolic $\mathrm{Ca}$ in amelioration of $\mathrm{Ni}$ toxicity in the $\mathrm{Ni}$ hyperaccumulating plant Alyssum inflatum. In an untransformed cell, cytosolic Ca concentration is higher than in a transformed cell (which has a promoted $C A X 1$ expression). $C A X 1$ concentrates $\mathrm{Ca}$ in the vacuole, resulting in $\mathrm{Ca}$ removal from the cytosol. $\mathrm{Ni}$ ions that enter cells are partially

and $200 \mu \mathrm{M}$ ), however, differences were significant, with less $\mathrm{Ni}$ in transformed calli. Nickel uptake in untransformed calli increased steadily with increased $\mathrm{Ni}$ in the medium, however, transformed calli only contained significantly increased $\mathrm{Ni}$ when $\mathrm{Ni}$ medium concentration was $200 \mu \mathrm{M}$ (Fig. 4).

\section{Discussion}

The exceedingly low $\mathrm{Ca}: \mathrm{Mg}$ quotients typical of serpentine soils, including in soils where Alyssum inflatum is found (Ghasemi et al. 2015a, b), require specialized physiological mechanisms to maintain adequate cytosolic Ca concentrations (Bradshaw 2005; Palm and Van Volkenburgh 2014). Such mechanisms may include a greater acquisition of $\mathrm{Ca}$ (Asemaneh et al. 2007), the exclusion of Mg (Madhok and Walker 1969; Sambatti and Rice 2007; but see Palm et al. 2012), and the restriction of $\mathrm{Ca}$ transport into the central vacuole, thereby maintaining high cytosolic $\mathrm{Ca}$ levels as suggested by Bradshaw (2005).

High cytosolic $\mathrm{Ca}$ can influence tolerance to heavy metals, including those that are found at high levels in serpentine soils (Yusuf et al. 2011; Gall and Rajakaruna 2013). Calcium-mediated metal tolerance appears to be influenced by cation/proton antiporters $(C A X)$, a group

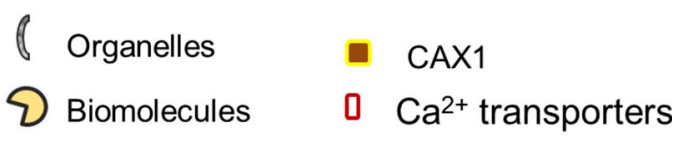

$\left[\mathrm{Ca}^{2+}\right]$ cyt $\downarrow$ : Damage by $\mathrm{Ni}$

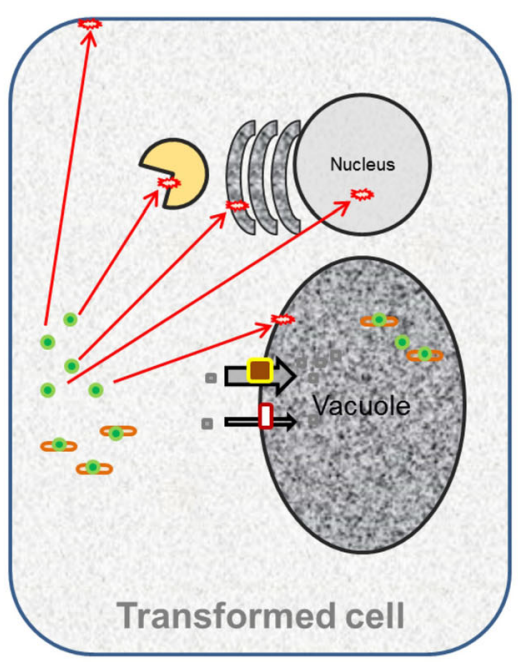

chelated and finally sequestered in the central vacuole, but $\mathrm{Ni}$ that remains free could potentially harm membranes, biomolecules, organelles, and nucleic acids. High cytosolic $\mathrm{Ca}$ concentration protects untransformed cells from Ni toxicity whereas, in transformed cells, Ni becomes toxic due to low cytosolic Ca concentrations

of proteins that export cations from the cytosol to the vacuole to maintain cellular ion homeostasis (Pittman and Hirschi 2003; Cheng et al. 2005; Mei et al. 2009; Connorton et al. 2012; Punshon et al. 2012; Pittman and Hirschi 2016). Transgenic tobacco plants expressing $C A X 1$ display symptoms of $\mathrm{Ca}$ deficiency, including hypersensitivity to ion imbalances and cold shock, but increased $\mathrm{Ca}$ in the medium was able reverse these sensitivities (Hirschi 1999). Interestingly, Shigaki et al. (2005) show that a histidine to alanine mutation at position 338 within Arabidopsis CAX1 can influence the transport function of $C A X 1$, leading to an increase in $\mathrm{Cd}$ and $\mathrm{Zn}$ transport and a sharp decline in Ca transport. The mutants also were more tolerant of the heavy metals, providing insights into the role of CAX1 in metal mobilization and tolerance. Baliardini et al. (2015) showed that $C A X 1$ expression in both roots and shoots was higher in the $\mathrm{Cd}$ hyperaccumulator Arabidopsis halleri than in two Cd-sensitive congeners, A. lyrata (L.) O'Kane \& Al-Shehbaz and A. thaliana. Moreover, $C A X 1$ loss of function in $A$. thaliana led to higher Cd sensitivity at low concentration of $\mathrm{Ca}$, higher sensitivity to methyl-viologen, and a greater accumulation of reactive oxygen species (ROS) following Cd treatment. The expression of an Arabidopsis CAX1 in petunia plants also enhances $\mathrm{Cd}$ tolerance and accumulation (Wu et al. 2011). These studies confirm the roles of $C A X$ 
antiporters in an increasing range of cellular and physiological functions, including metal transport and tolerance, and especially of Cd (Hirschi et al. 2000; Mei et al. 2009; Pittman and Hirschi 2016).

However, there has been no evidence to date of $C A X$ mediated $\mathrm{Ni}$ tolerance. Unlike in previous studies of $C A X$-mediated metal tolerance, $C A X 1$ did not increase Ni tolerance in our experiment, suggesting that it does not act as a specific Ni transporter. To date, there is no evidence for $\mathrm{a} \mathrm{Ni}^{2+} / \mathrm{H}^{+}$antiporter or a nucleotide-dependent Ni pump, suggesting either that the vacuole is not a major site for Ni accumulation (Brune et al. 1995; Gries and Wagner 1998) or that $\mathrm{Ni}$ exclusion is a mechanism of tolerance (Burrell et al. 2012). We propose that transformation of a $\mathrm{Ni}$ hyperaccumulator plant by $C A X 1$ leads to decreased cytosolic $\mathrm{Ca}$ in transformed cells (due to increased transport of $\mathrm{Ca}$ to the vacuole). Under decreased cytosolic Ca levels, other Ni tolerance mechanisms (Yusuf et al. 2011; Gall and Rajakaruna 2013) are likely inadequate for reducing Ni toxicity, especially in Ni hyperaccumulator plants. A minimum cytosolic $\mathrm{Ca}$ concentration may be necessary for $\mathrm{Ni}$ tolerance in $\mathrm{Ni}$ hyperaccumulators such as $A$. inflatum, even in the presence of constitutive $\mathrm{Ni}$ detoxifying mechanisms (Ghasemi et al. 2015a, b). This is especially critical in serpentine soils, where soil $\mathrm{Ca}$ is generally low compared to $\mathrm{Mg}$ and Ni (Bradshaw 2005; Palm et al. 2012).

Although the role of $\mathrm{Ca}$ in increasing metal (including $\mathrm{Ni}$ ) tolerance has previously been documented (Chaney et al. 2008; Siddiqui et al. 2011; Aziz et al. 2015), the exact mechanisms involved in minimizing toxicity are not always elaborated. Further, there is limited work to date examining the role of $C A X 1$ in serpentine tolerance, including in the tolerance of Ni. A pioneering study by Bradshaw (2005) showed that $C A X I$ mutants of Arabidopsis thaliana exhibit greater tolerance to Ca-deficient serpentine soils and he suggested this was due to higher cytoplasmic $\mathrm{Ca}$ (resulting from decreased transport to the vacuole). Our study demonstrates that modification of callus $\mathrm{Ca}$ levels is associated with change in tolerance to $\mathrm{Ni}$, a metal that is found in high concentrations in serpentine soils. Alyssum inflatum calli transformed with $C A X 1$ showed an increase in $\mathrm{Ca}$ concentrations (Fig. 2) and a decreased tolerance to $\mathrm{Ni}$ compared with untransformed calli (Fig. 3). These results suggest that decreased cytosolic $\mathrm{Ca}$, in response to transformation with $C A X 1$, could lead to decreased $\mathrm{Ni}$ tolerance, suggesting that other $\mathrm{Ni}$ tolerance mechanisms, including complexation and vacuolar sequestration (Yusuf et al. 2011), are not sufficient for $\mathrm{Ni}$ tolerance at low cytosolic Ca concentrations.

We propose that serpentine tolerant and $\mathrm{Ni}$-hyperaccumulating plants keep cytosolic $\mathrm{Ca}$ as high as possible to prevent $\mathrm{Ni}$ toxicity. Enhanced cytosolic $\mathrm{Ca}$ may be achieved via increasing Ca uptake and/or decreasing the activities of outward transporters (such as $C A X I$ ) which transport $\mathrm{Ca}$ into the apoplast or internal compartments such as vacuoles. A possible lack of $C A X 1$ activity in serpentine tolerant plants may allow them to maintain high cytosolic $\mathrm{Ca}$ despite low soil $\mathrm{Ca}$ and thereby tolerate the high cytosolic Ni concentrations found in Ni-hyperaccumulating plants. The lack of $C A X 1$ activity may also necessitate a lower requirement for $\mathrm{Ca}$ due to a higher sensitivity to increased $\mathrm{Ca}$ in serpentine-adapted plants (Ghasemi et al. 2015a, b); for example, A. inflatum is sensitive to both high temperature and nitrogen under higher soil $\mathrm{Ca}: \mathrm{Mg}$ compared to A. lanceolatum, its non-serpentine congener. It is unknown if the tolerance threshold for cytosolic $\mathrm{Ca}$, in general, is lower for serpentine-adapted plants than their serpentine-intolerant congeners or whether Ni tolerance in serpentine endemic plants can be achieved under lower cytosolic $\mathrm{Ca}$ than what would be needed for serpentine-intolerant or serpentine-tolerant but non-endemic congeners.

Our results imply that decreased cytosolic Ca resulting from transformation with $C A X 1$ leads to decreased $\mathrm{Ni}$ tolerance. This, in turn, suggests that other Ni tolerance mechanisms (including complexation and vacuolar sequestration) are not sufficient for Ni tolerance at low cytosolic $\mathrm{Ca}$ concentrations. As summarized in Fig. 5, we propose that high cytosolic $\mathrm{Ca}$ is essential for $\mathrm{Ni}$ tolerance in $\mathrm{Ni}$ hyperaccumulator plants and hypothesize that this may be a common pathway for metal tolerance in serpentine plants. However, there are several shortcomings in our approach, as well the need for additional investigation to confirm our results. Future studies that measure cytosolic and vacuolar $\mathrm{Ca}$ concentrations in wild-type and transformed plants will be needed to confirm our hypothesized mechanism. In addition, we limited our investigation of the role of $\mathrm{Ca}$ in Ni tolerance to A. inflatum calli: future studies should examine Ni tolerance using whole plants. Additionally, it is important to measure gene expression in both calli and transformed plants and measure cystosolic $\mathrm{Ca}$ in relation to Ni tolerance. It is also important to compare expression of $C A X 1 \mathrm{mRNA}$ and protein in $A$. inflatum (a serpentine endemic and $\mathrm{Ni}$ hyperaccumulator) with that in its closest non-serpentine relative (A. lanceolatum Baumg.) to determine whether $A$. inflatum lacks $C A X 1$ expression. If the serpentine endemic shows any $C A X 1$ expression, the $C A X 1$ gene can be cloned, sequenced, and examined for defects that would prevent normal $C A X 1$ function. $C A X 1$ genes cloned from any Alyssum taxon could also be directly tested for function in transgenic Arabidopsis thaliana or yeast. Finally, quantitative trait locus mapping in crosses between $A$. inflatum and A. lanceolatum could provide a comprehensive understanding of the genetic architecture of serpentine tolerance in Alyssum, identifying candidate genes (such as $C A X 1$ ) for serpentine tolerance.

Acknowledgements We thank Prof. K. D. Hirschi (Baylor College of Medicine, Texas Medical Center in Houston, TX, USA) for providing plasmids for this research (including the $C A X 1$ gene). This work was supported by a research grant to R. G. awarded by Payam Noor University, Iran. Funding to N. R. from the US-SL Fulbright Commission is also gratefully acknowledged. 


\section{References}

Abul Kashem MDA, Kawai S (2007) Alleviation of cadmium phytotoxicity by magnesium in Japanese mustard spinach. J Soil Sci Plant Nutr 53:246-251

Ahmad MS, Ashraf M (2011) Essential roles and hazardous effects of nickel in plants. Rev Environ Contam Toxicol 214:125-167

Amari T, Lutts S, Taamali M, Lucchini G, Sacchi GA, Abdelly C, Ghnaya $T$ (2016) Implication of citrate, malate and histidine in the accumulation and transport of nickel in Mesembryanthemum cristallinum and Brassica juncea. Ecotoxicol Environ Saf 126:122-128

An G, Ebert PR, Mitra A, Ha SB (1988) Binary Vectors. In: Gelvin SB, Schilperoort RA (eds) Plant molecular biology manual. Kluwer Academic Publishers, Great Britain, pp 1-19

Anacker BL (2011) Phylogenetic patterns of endemism and diversity. In: Harrison SP, Rajakaruna N (eds) Serpentine: the evolution and ecology of a model system. University of California Press, Berkeley, pp 49-79

Anacker BL (2014) The nature of serpentine endemism. Am J Bot 101:219-224

Antosiewicz DM, Hennig J (2004) Overexpression of LCT1 in tobacco enhances the protective action of calcium against cadmium toxicity. Environ Poll 129:237-245

Arnold BJ, Lahner B, DaCosta JM, Weisman CM, Hollister JD, Salt DE, Bomblies K, Yant L (2016) Borrowed alleles and convergence in serpentine adaptation. Proc Nat Acad Sci USA 113:8320-8325

Asemaneh T, Ghaderian SM, Baker AJM (2007) Responses to Mg/ $\mathrm{Ca}$ balance in an Iranian serpentine endemic plant, Cleome heratensis (Capparaceae) and a related non-serpentine species, C. foliosa. Plant Soil 293:49-59

Aziz H, Sabir M, Ahmad HR, Aziz T, Rehman MZ, Hakeen KR, Ozturk M (2015) Alleviating effect of calcium on nickel toxicity in rice. Clean Soil Air Water 43:901-909

Baliardini C, Meyer C, Salis P, Saumitou-Laprade P, Verbruggen N (2015) Cation Exchanger1 cosegregates with cadmium tolerance in the metal hyperaccumulator Arabidopsis halleri and plays a role in limiting oxidative stress in Arabidopsis spp. Plant Physiol 169:549-559

Boyd RS (2014) Ecology and evolution of metal-hyperaccumulator plants. In: Rajakaruna N, Boyd RS, Harris T (eds) Plant ecology and evolution in harsh environments. Nova Science Publishers, Hauppauge, pp 227-241

Bradshaw HD Jr (2005) Mutations in CAX1 produce phenotypes characteristic of plants tolerant to serpentine soils. New Phytol 167:81-88

Brady KU, Kruckeberg AR, Bradshaw HD Jr (2005) Evolutionary ecology of plant adaptation to serpentine soils. Annu Rev Ecol Evol Syst 36:243-266

Brune A, Urbach W, Dietz KJ (1995) Differential toxicity of heavy metals is partly related to a loss of preferential extraplasmic compartmentation: a comparison of $\mathrm{Cd}, \mathrm{Mo}, \mathrm{Ni}$ and $\mathrm{Zn}$ stress. New Phytol 129:403-409

Burrell AM, Hawkins AK, Pepper AE (2012) Genetic analyses of nickel tolerance in a North American serpentine endemic plant, Caulanthus amplexicaulus var. barbarae (Brassicaceae). Am J Bot 99:1875-1883

Bush DS (1995) Calcium regulation in plant cells and its role in signaling. Annu Rev Plant Physiol Plant Mol Biol 46:95-122

Cappa JJ, Pilon-Smits EA (2014) Evolutionary aspects of elemental hyperaccumulation. Planta 239:267-275

Cecchi L, Gabbrielli R, Arnetoli M, Gonelli C, Hasko A, Selvi F (2010) Evolutionary lineages of nickel hyperaccumulation in systematics in European Alysseae (Brassicaceae): evidence from nrDNA sequence data. Ann Bot 106:751-767

Chaney RL, Chen KY, Li YM, Angle JS, Baker AJM (2008) Effects of calcium on nickel tolerance and accumulation in Alyssum species and cabbage grown in nutrient solution. Plant Soil 311:131-140
Cheng NH, Pittman JK, Bronwyn JB, Shigaki T, Hirschi KD (2003) The Arabidopsis caxl mutant exhibits impaired ion homeostasis, development, and hormonal responses and reveals interplay among vacuolar transporters. Plant Cell 15:347-364

Cheng NH, Pittman JK, Shigaki T, Lachmansingh J, LeClere S, Lahner B, Salt DE, Hirschi KD (2005) Functional association of Arabidopsis CAX1 and CAX3 is required for normal growth and ion homeostasis. Plant Physiol 138:2048-2060

Chou TS, Chao YY, Huang WD, Hong CY, Kao CH (2011) Effect of magnesium deficiency on antioxidant status and cadmium toxicity in rice seedlings. J Plant Physiol 168:1021-1030

Connorton JM, Webster RE, Cheng N, Pittman JK (2012) Knockout of multiple Arabidopsis cation $/ \mathrm{H}^{+}$exchangers suggests isoform-specific roles in metal stress response, germination and seed mineral nutrition. PLoS ONE 7(10):e47455

Ditt RF, Nester EW, Comai L (2001) Plant gene expression response to Agrobacterium tumefaciens. Proc Nat Acad Sci USA 98:10954-10959

Doubkova P, Sudova R (2014) Nickel tolerance of serpentine and non-serpentine Knautia arvensis plants as affected by arbuscular mycorrhizal symbiosis. Mycorrhiza 24:209-217

Eller F, Brix H (2016) Influence of low calcium availability on cadmium uptake and translocation in a fast-growing shrub and a metal-accumulating herb. AoB Plants 8:143

Freeman JL, Persans MW, Neiman K, Albrecht C, Peer W, Pickering IJ, Salt DE (2004) Increased glutathione biosynthesis plays a role in nickel tolerance in Thlaspi nickel hyperaccumulators. Plant Cell 16:2176-2191

Gabbrielli R, Pandolfini T (1984) Effect of $\mathrm{Mg}^{2+}$ and $\mathrm{Ca}^{2+}$ on the response to nickel toxicity in a serpentine endemic and nickel accumulating species. Physiol Plant 62:540-544

Gabbrielli R, Grossi L, Vergnano O (1989) The effects of nickel, calcium and magnesium on the acid phosphatase activity of two Alyssum species. New Phytol 111:631-636

Gall JE, Rajakaruna N (2013) The physiology, functional genomics, and applied ecology of heavy metal-tolerant Brassicaceae. In: Lang $M$ (ed) Brassicaceae: characterization, functional genomics and health benefits. Nova Science Publishers, New York, pp 121-148

Ghasemi R, Ghaderian SM (2009) Responses of two populations of an Iranian nickel-hyperaccumulating serpentine plant, Alyssum inflatum Nyar. to substrate $\mathrm{Ca} / \mathrm{Mg}$ quotient and nickel. Environ Exp Bot 67:260-268

Ghasemi R, Ghaderian SM, Krämer U (2009a) Accumulation of nickel in trichomes of a nickel hyperaccumulator plant, Alyssum inflatum. Northeast Nat 16:81-92

Ghasemi R, Ghaderian SM, Krämer U (2009b) Interference of nickel with copper and iron homeostasis contributes to metal toxicity symptoms in the nickel hyperaccumulator plant Alyssum inflatum. New Phytol 184:566-580

Ghasemi R, Chavoshi ZZ, Boyd RS, Rajakaruna N (2015a) A preliminary study of the role of nickel in enhancing flowering of the nickel hyperaccumulating plant Alyssum inflatum Nyar. (Brassicaceae). S Afr J Bot 92:47-52

Ghasemi R, Chavoshi Z, Ghaderian SM (2015b) Stenocalcic properties in the serpentine-endemic plant Alyssum inflatum Nyarady. Aust J Bot 63:31-38

Gong M, Chen SN, Song YQ, Li ZG (1997a) Effect of calcium and calmodulin on intrinsic heat tolerance in relation to antioxidant systems in maize seedlings. Aust J Plant Physiol 24:371-379

Gong M, Li YJ, Dai X, Tian M, Li ZG (1997b) Involvement of calcium and calmodulin in the acquisition of HS induced thermotolerance in maize seedlings. J Plant Physiol 150:615-621

Gries GE, Wagner GJ (1998) Association of nickel versus transport of cadmium and calcium in tonoplast vesicles of oat roots. Planta 204:390-396

Harrison SP, Rajakaruna N (eds) (2011) Serpentine: the evolution and ecology of a model system. University of California Press, Berkeley, pp 49-79

Heikal MMD, Berry WL, Wallace A, Herman D (1989) Alleviation of nickel toxicity by calcium salinity. Soil Sci 147:413-415 
Hepler PK (2005) Calcium: a central regulator of plant growth and development. Plant Cell 17:2142-2155

Hirschi KD (1999) Expression of Arabidopsis CAX1 in tobacco: altered calcium homeostasis and increased stress sensitivity. Plant Cell 11:2113-2122

Hirschi KD (2004) The calcium conundrum. Both versatile nutrient and specific signal. Plant Physiol 136:2438-2442

Hirschi KD, Korenkov VD, Wilganowski NL, Wagner GJ (2000) Expression of Arabidopsis CAX2 in tobacco. Altered metal accumulation and increased manganese tolerance. Plant Physiol 124:125-133

Ingle RA, Mugford ST, Rees JD, Campbell MM, Smith JAC (2005) Constitutively high expression of the histidine biosynthetic pathway contributes to nickel tolerance in hyperaccumulator plants. Plant Cell 17:2089-2106

Izosimova A (2005) Modelling the interaction between calcium and nickel in the soil-plant system. Dissertation, Technical University of Braunschweig, Germany

Jauregui Zùñiga D, Ferrer MA, Calderon AA, Muñoz R, Moreno A (2005) Heavy metal stress reduces the deposition of calcium oxalate crystals in leaves of Phaseolus vulgaris. J Plant Physiol $162: 1183-1187$

Jenny H (1980) The soil resource: origin and behavior. Springer, New York

Jiang Y, Huang B (2001) Effect of calcium on antioxidant activities and water relations associated with heat tolerance in two coolseason grasses. J Exp Bot 355:341-349

Johnston WR, Proctor J (1981) Growth of serpentine and nonserpentine races of Festuca rubra in solutions simulating the chemical conditions in a toxic serpentine soil. J Ecol 69:855-869

Johnston WR, Proctor J (1984) The effects of magnesium, nickel, calcium and micronutrients on the root surface phosphatase activity of a serpentine and nonserpentine clone of Festuca rubra L. New Phytol 96:95-101

Kay KM, Ward KL, Watt LR, Schemske DW (2011) Plant speciation. In: Harrison SP, Rajakaruna N (eds) Serpentine: the evolution and ecology of a model system. University of California Press, Berkeley, pp 71-95

Kazakou EP, Dimitrakopoulos G, Baker AJM, Reeves RD, Troumbis AY (2008) Hypotheses, mechanisms, and trade-offs of tolerance and adaptation to serpentine soils: from species to ecosystem level. Biol Rev 83:495-508

Li L, Tutone AF, Drummond RSM, Gardner RC, Luan S (2001) A novel family of magnesium transport genes in Arabidopsis. Plant Cell 13:2761-2775

Lopez Climent MF, Arbona V, Perez Clemente RM, Zandalinas SI, Gomez Cadenas A (2014) Effect of cadmium and calcium treatments on phytochelatin and glutathione levels in citrus plants. Plant Biol 16:79-87

Madhok OP, Walker RB (1969) Magnesium nutrition of two species of sunflower. Plant Physiol 44:1016-1022

Main JL (1981) Magnesium and calcium nutrition of a serpentine endemic grass. Am Midl Nat 105:196-199

Matraszek R, Hawrylak Nowak B (2010) Growth and mineral composition of nickel-stressed plants under conditions of supplementation with excessive amounts of calcium and iron. $\mathrm{J}$ Toxicol Environ Health A 73:1260-1273

Mei H, Cheng NH, Zhao J, Park S, Escareno RA, Pittman JK, Hirschi KD (2009) Root development under metal stress in Arabidopsis thaliana requires the $\mathrm{H}^{+}$/cation antiporter CAX4. New Phytol 183:95-105

Meindl GA, Bain DJ, Ashman TL (2014) Nickel accumulation in leaves, floral organs and rewards varies by serpentine affinity. AoB Plants 6:plu036

Mozafari H, Asrar Z, Rezanejad F, Pourseyedi S, Yaghoobi MM (2014) Oxidative stress tolerance by calcium and histidine in two tomato cultivars under nickel stress. J Stress Physiol Biochem 10:102-124

Murashige T, Skoog F (1962) A revised medium for rapid growth and bio assays with tobacco tissue cultures. Physiol Plant $15: 473-497$
O'Dell RE, Claassen VP (2006) Serpentine and nonserpentine Achillea millefolium accessions differ in serpentine substrate tolerance and response to organic and inorganic amendments. Plant Soil 279:253-269

O'Dell RE, Rajakaruna N (2011) Intraspecific variation, adaptation, and evolution. In: Harrison SP, Rajakaruna N (eds) Serpentine: the evolution and ecology of a model system. University of California Press, Berkeley, pp 97-137

O'Dell RE, James JJ, Richards JH (2006) Congeneric serpentine and nonserpentine shrubs differ more in leaf $\mathrm{Ca}$ : $\mathrm{Mg}$ than tolerance of low N, low P, or heavy metals. Plant Soil 280:49-64

Palm ER, Van Volkenburgh E (2014) Physiological adaptations of plants to serpentine soil. In: Rajakaruna N, Boyd RS, Harris T (eds) Plant ecology and evolution in harsh environments. Nova Science Publishers, Hauppauge, pp 129-148

Palm E, Brady K, Van Volkenburgh EV (2012) Serpentine tolerance in Mimulus guttatus does not rely on exclusion of magnesium. Funct Plant Biol 39:679-688

Pittman JK, Hirschi K (2003) Don't shoot the (second) messenger: endomembrane transporters and binding proteins modulate cytosolic $\mathrm{Ca}^{2+}$ levels. Curr Opin Plant Biol 6:257-262

Pittman JK, Hirschi KD (2016) CAX-ing a wide net: cation/H + transporters in metal remediation and abiotic stress signaling. Plant Biol 18:741-749

Polacco JC, Mazzafera P, Tezotto T (2013) Nickel and urease in plants: still many knowledge gaps. Plant Sci 199-200:79-90

Pollard AJ, Powell KD, Harper FA, Smith JAC (2002) The genetic basis of metal hyperaccumulation in plants. Critic Rev Plant Sci 21:539-566

Porebski S, Bailey LG, Baum BR (1997) Modification of a CTAB DNA extraction protocol for plants containing high polysaccharide and polyphenol components. Plant Mol Biol Rep 15:815

Porter SS, Chang PL, Conow CA, Dunham JP, Friesen ML (2016) Association mapping reveals novel serpentine adaptation gene clusters in a population of symbiotic Mesorhizobium. ISME J $11: 248-262$

Punshon T, Hirschi K, Yang J, Lanzirotti A, Lai B, Guerinot ML (2012) The role of CAX1 and CAX3 in elemental distribution and abundance in Arabidopsis seed. Plant Physiol 158:352-362

Rajakaruna N, Yaeesh Siddiqi M, Whitton J, Bohm BA, Glass ADM (2003) Differential responses to $\mathrm{Na}^{+} / \mathrm{K}^{+}$and $\mathrm{Ca}^{2+} /$ $\mathrm{Mg}^{2+}$ in two edaphic races of the Lasthenia californica (Asteraceae) complex: a case for parallel evolution of physiological traits. New Phytol 157:93-103

Rajakaruna N, Harris TB, Alexander EB (2009) Serpentine geoecology of eastern North America: a review. Rhodora 111:21108

Rengel Z (1992) Role of calcium in aluminum toxicity. New Phytol 121:499-513

Sambatti JBM, Rice KJ (2007) Functional ecology of ecotypic differentiation in the Californian serpentine sunflower (Helianthus exilis). New Phytol 175:107-119

Selby JP, Jeong AL, Toll K, Wright KM, Lowry DB (2014) Methods and discoveries in the pursuit of understanding the genetic basis of adaptation to harsh environments in Mimulus. In: Rajakaruna N, Boyd RS, Harris T (eds) Plant ecology and evolution in harsh environments. Nova Science Publishers, Hauppauge, pp 243-266

Shigaki T, Barkla BJ, Miranda-Vergara MC, Zhao J, Pantoja O, Hirschi KD (2005) Identification of a crucial histidine involved in metal transport activity in the Arabidopsis cation $/ \mathrm{H}^{+}$exchanger CAX1. J Biol Chem 280:30136-30142

Siddiqui MH, Al-Whaibi MH, Basalah MO (2011) Interactive effect of calcium and gibberellin on nickel tolerance in relation to antioxidant systems in Triticum aestivum L. Protoplasma 248:503-511

Siddiqui MH, Al Whaibi MH, Sakran AM, Basaleh MO, Ali HM (2012) Effect of calcium and potassium on antioxidant system of Vicia faba L. under cadmium stress. Int J Mol Sci 13:66046619 
Tang R-J, Zhao F-G, Garcia VJ, Kleist TJ, Yang L, Zhang H-X, Luan S (2015) Tonoplast CBL-CIPK calcium signaling network regulates magnesium homeostasis in Arabidopsis. Proc Nat Acad Sci USA 112:3134-3139

Tarczynski MC, Meyer WJ, Min JJ, Wood KA, Hellwig RJ (1994) Two-minute miniprep method for plasmid DNA isolation. Biotechniques 16:514-519

Turner TL, von Wettberg EJ, Nuzhdin SV (2008) Genomic analysis of differentiation between soil types reveals candidate genes for local adaptation in Arabidopsis lyrata. PLoS ONE 3(9):e3183

Turner TL, Bourne EC, von Wettberg EJ, Hu TT, Nuzhdin SV (2010) Population resequencing reveals local adaptation of Arabidopsis lyrata to serpentine soils. Nat Genet 42:260-263

Van der Ent A, Baker AJM, Reeves RD, Pollard AJ, Schat H (2013) Hyperaccumulators of metal and metalloid trace elements: facts and fiction. Plant Soil 362:319-334

Veatch Blohm ME, Roche BM, Campbell M (2013) Evidence for cross-tolerance to nutrient deficiency in three disjunct populations of Arabidopsis lyrata ssp. lyrata in response to substrate calcium to magnesium ratio. PLoS ONE 8(5):e63117
Verbruggen N, Hermans C, Schat H (2009) Molecular mechanisms of metal hyperaccumulation in plants. New Phytol 181:759-776

Vergnano Gambi O, Gabbrielli R, Pandolfini T (1992) Some aspects of the metabolism of Alyssum bertolonii Desv. In: Baker AJM, Proctor J, Reeves RD (eds) The vegetation of ultramafic (serpentine) soils. Intercept, Andover, pp 319-332

Von Wettberg EJ, Wright JW (2011) Genomic approaches to understanding adaptation. In: Harrison SP, Rajakaruna N (eds) Serpentine: the evolution and ecology of a model system. University of California Press, Berkeley, pp 139-153

White PJ, Broadley MR (2003) Calcium in plants. Ann Bot 92:487511

Wu Q, Shigaki T, Williams KA, Han JS, Kim CK, Hirschi KD, Park S (2011) Expression of an Arabidopsis $\mathrm{Ca}^{2+} / \mathrm{H}^{+}$antiporter CAX1 variant in petunia enhances cadmium tolerance and accumulation. J Plant Physiol 168:167-173

Yusuf M, Fariduddin Q, Hayat S, Ahmad A (2011) Nickel: an overview of uptake, essentiality and toxicity in plants. B Environ Contam Tox 86:1-17 